\title{
The Concept of Land/Earth in the Old Testament and in Africa: Implications to the Contemporary Nigerian Christian
}

\author{
Obedben Mmesomachukwu Lumanze \\ https://dx.doi.org/10.4314/jrhr.v13i1.4
}

\begin{abstract}
The earth/land is an important asset that God gavelentrusted to humankind to care for. It is "alive" and responsive to [G]od, humanity and other creatures. The objective of this study was to discover the relationship between Old Testament idea of the concept of land and that of Africa and then the implications of these ideas to the contemporary Christian. The methodologies adopted for the study are the historical method and ecological hermeneutics. The study emphasizes that God gave humankind the earth to explore and not exploit. Humans are thus to maintain harmony in the ecosystem and sustainability of natural resources.
\end{abstract}

Keywords: African(s), Earth/Land, Old Testament, God, Genesis, Creation Care.

\section{Introduction}

From the Old Testament creation account it is obvious that originally, the LORD God created a beautiful and serene earth/environment (cf. Gen. 1:1-2:8-15). For that reason, afterward, in many occasions, He admonishes His people, the Israelites, to value and take care of their environment including the animals, trees and non-living organisms. Thus, even the land and animals were to also enjoy the Sabbath (cf. Exod. 20:10; Lev. 25:4; Deut. 5:14; 20:19).

Before the coming of the European slave masters to Africa, Africans understood the earth/land to have been created by the [G]ods. The land/earth was thus seen as a sacred entity that should be 
cherished and respected. Trees, seas, animals and non-human organisms were preserved and not exploited/abused. This was partly because for traditional Africans, the physical world and the spiritual were interdependent- that is, they interacted with each other. Accordingly, there was no distinction or clear boundary between the two worlds. However, it was not until the West came with the[ir] ideas/philosophies of dualism, individualism, capitalism, and secular humanism that these African worldviews began to change or erode. It is based on the above incidence that this study was carried out. It is unfortunate that many people; including Christians do not know the importance of the theme of "land" in the Old Testament especially the Torah. Many Christians are yet to realize that the theme has theological relevance to the post-modern man.

The objective of this study was thus to bring to light the relationship between Old Testament idea of the earth/land and that of Africa and then note some of the implications of these ideas to the contemporary Nigerian Christian. The methodologies or models adopted for the study are the historical method and "ecological hermeneutics".

\section{The Concept of Earth/Land in the Old Testament}

The theme, "earth/land" is a very important one in the Old Testament and/or in Hebrew religion. In the Old Testament, the terms, "earth" and "land" are often used interchangeably. However, there are three major Hebrew words denoting "land" in the book of Genesis. They include 'eres, (referring to both "earth" and "land"), 'adamah and then sadeh. Although these Hebrew terms/words are often used synonymously; each of them has its own emphasis. All the same, among the three, 'eres is used or mentioned more frequently. Though it occasionally denotes "ground" (cf. Gen. 18:2; cf. Exod. 4:3; Deut. $15: 23$ ), often, it is also used to refer to large stretches of territory, a region, or country (cf. Gen. 12: 1, 5; 17:8; cf. Exod. 2:15; Lev. 11:45; 
Num. 13:2). 'eres could also be referred to as the earth as a whole (cf. Gen. $1: 1 ; 2: 1 ; 6: 4 ; 11: 1$; cf. Deut. 28:25). More to the point, Dewitt (1991) observes that "land", in the Old Testament includes "humans, animals, birds, fish and other non-human elements".

The second word, 'adamah may also denote the earth; that is, the livable human environment (Gen. 12:3) or a particular country (cf. Gen. 47:20). But in most cases, it refers to the "soil" or the "ground" (Gen. 2:5,7,19; 3:17,19,23; 4:2,3,10; cf. Exod. 3:5; Lev. 20:25; Deut. $4 ; 18)$. The third word, Sadeh rarely talks about a particular country (Gen. 14:7); it usually refers to cultivated land (Gen. 37:7; cf. Exod. 9:22; 10:5; Num. 16:14; Deut. 11:15) or to the open countryside (Gen. $2: 19,20 ; 3: 1,14 ; 25: 27,29$; cf. Exod. 23:11; Deut. 22:25).For example, in Genesis 23:8-20, the term, Sadeh is used in relation to the land that the patriarch, Abraham bought from the Hittites to bury his wife, Sarah.

From the above explanations, it is obvious that though the three Hebrew words translated land/earth are closely related in meaning, they have slight distinction. Moreover, as earlier noted, for the Hebrew, "land" was a very important theme and asset. This is because, the earth and everything on it, was created by the LORD God. Brueggemann (2002) has therefore described it as the central theme of biblical faith. Habel (2008) corroborates that it is such a significant and comprehensive and/or widespread symbol in the Old Testament that it could be ranked next to "God" in importance. McKeown (2006) adds that closely related to the themes of "descendent" and "blessing" is the theme of "land". The above comments show how important this theme was for the ancient Israelites.

According to McKeown (2006), in Genesis, discussions about "land" fall into two main categories. First, land in chapters 1-11 is approached with an emphasis on creation and ecological issues. Second, studies of land in chapters 12-50 usually focus on the 
promise of land to the patriarchs. Chapters 1-11 show that God is sovereign over all lands (the whole earth). He is portrayed as both the "Creator" and "Supreme Landlord". Consequently, He is the one that allocates land to people and gives them work to do on it. God makes man responsible for cultivating the ground and keeping it under control (cf. Gen. 1:28; 2:8) (Keil, 1980).

Many scholars believe that theologically, "the theme of "land" in the Old Testament began with Paradise." Though, according to Genesis 3, this "paradisiacal" nature was lost to the fall of man; however, Ucheawaji (2013) citing Robertson, still affirms that this land/earth belongs to the Lord of the covenant (p. 25). In Leviticus 25: 23, the LORD God makes it clear that "The land shall not be sold forever: for the land is mine, and you are strangers (tenants) and sojourners with me" He goes ahead to proclaim, "All the blessings flowing from the land (earth) come ultimately from the hand of the Lord." Accordingly, Ucheawaji (2013) opines that this land "is uniquely holy." [And this] holiness of the land is derived from the presence of the holy God, the Creator" (p. 25). The point been made here is that the earth is not evil; it is holy (and should be treated so) because a holy God created it. Many people, including Christians have this whole distorted view about the earth. They often have the notion that the land/earth is intrinsically evil and that God almighty has abandoned it and no longer interested in what happens in/to it. The point however is, the earth/land only became cheapened or denigrated so to say, because humanity made it so. But from the beginning, it was not so. At creation, the LORD God confirmed and certified that the material world (of which the land is part of), was good and very good. God appreciated all that $\mathrm{He}$ had created including the earth/land (Gen. 1:31). All that He, the LORD God made was thus "holy" and "good" because He, the Creator, is holy and good. For this reason, Ucheawaji (2013) further maintains, "The 
holiness of the Lord so penetrates the land, that it may be said that it is proactive in maintaining its own sacredness" (p. 25).

In the Old Testament, there is often a physical dimension to the concept of holiness. Thus, when God commanded His people, the Israelites to be holy, it was both in the spiritual and physical sense. Holiness consequently, entailed washing their clothes, keeping their environment clean and not messing it with human excreta; bathing, not going near or touching dead animals, and having rest (the Sabbath) and so on (Exod. 16:23; 19: 10; 22:31; 29:4; Deut. 21:6; 23:13). Though, many Christians often spiritualize/allegorize some of these texts; they are literal and should first be taken and approached in/from that sense. Interpreters thus, should not be quick to allegorize and/or spiritualize such texts; they have physical relevance/implications as well as spiritual.

\section{The Concept of Earth/Land in Africa}

Many traditional African societies and cultures have similar views of the earth/land with those of the Hebrews though there may be some differences. First, though many Africans believe that $[\mathrm{G}]$ od, the Supreme Being, is the chief creator, maintainer and sustainer of the universe; however, in many cultures, this [G]od created and runs the earth via lesser deities that he delegates authority to. There are many creation myths in this regard in Africa (Awolalu \& Dopamu, 1979). In most African cultures, land/earth is not just an inanimate object to be acquired as a property. Ucheawaji (2013) affirms, "In most African cultures, the earth/land is viewed as an animate entity, possibly, an actor" (p. 29). This shows that Africans have an elevated view of the land/earth. Kete Asante (2009) corroborates that in African cosmology, the earth/land is highly revered and the personification of the earth/land is common. Hence, in African aphorism, the earth/land is addressed as "Mother-Earth." Thus, for Africans, the earth/land is not a lifeless or unresponsive element. The Israelites also have this 
Lumanze: The Concept of Land/Earth in the Old Testament and in Africa: Implications to the Contemporary Nigerian Christian

view about the earth/land even though they were not permitted to worship or venerate it. In the BGT version of the Old Testament, gen is translated 'soil', 'earth' and 'ground'. It is translated from ge and is a noun, accusative, feminine, singular, common. Hence, the Hebrews/Israelites believed that the earth as an "animate unit" could bear witness (cf. Deuteronomy 4:25, 26).

\section{Various Creation Myths in Africa}

Many African peoples/cultures have the understanding that the creation of the earth/man began from a supreme being called Chineke - Creator God among the Igbo, Olodumare or Edumare, Olurunin Yoruba, Osanobua or Osanobwa in Edo, Soko in Nupe, Nana Buluku among the Ewe and Fon of Benin Republic, Nyame or Onyame among the Akan of Ghana, Ngewo among the Mende of Sierra-Leone, and the rest. Many of these and other African names of [G]od show that Africans have the idea of God as the Creator of the universe and all that is in it (Awolalu \& Dopamu, 1979, p. 54). According to Ikeke (2017), "In African understanding, there is no creation without God. God is the source and the power that gives life to creation. Everything exists because they were given life by God" (p. 310). Ubrurhe (2003) corroborates the above assertions. He affirms that in African worldview, "God is the creator of humans and the earth with all its constituents" (p. 30). Also, Gehman (2001) has recognized that man, in African religious worldview, "is the creation of the Supreme Being...[He] did not develop through evolution but came into being by the act of the Creator God"' (p. 36).

It is however despicable that many of the pioneering western missionaries and anthropologists in the past, denied that Africans had any idea or awareness of the Supreme Being (God). However, many Afro-centric scholars have established that these missionaries and anthropologists were wrong. Africans believed that the earth did not come by itself- there was a creator. Man was also believed to be part 
of the earth from which he has been taken (Mbiti, 1991; Idowu, 1973; Awolalu \& Dopamu, 1979).

There are many myths in African thought that describe how the earth and man was created by [G]od which cannot be fully discussed here. However, for the purpose of this study, three of these accounts will suffice. First, among the Igbo of Eastern Nigeria, Chukwu (the high [G]od) created the heaven and the earth when there was crisis in the domains of the Gods. This Chukwu designed the heavens and divided it into equal parts for each gods and goddesses. However, the god, Igwe and the goddess, Ala (Ani), was given the earth/land as their domain and they were the ones that then created humankind. They created four males and four females from sticks (the ofo tree as bones), and clay and chalk for the flesh. After the creation, the Igwe and Ala started educating these human creatures on how to survive on earth. In Igbo cosmology, the Ala is the legislature (she makes the laws); while Igwe is the executor of the laws of the land (Ala). Thus, in Igbo cosmology and/or pantheon, Igwe is the judge, protector, priest and the authority of $O f o$. After the creation of man, some gods were invited for the ceremony of the creation. Some of them included: Anyanwu (the he sun-god), Amadioha (the thunder and lightning god), Ekwensu (the swindler god), and the goddess of the moon (Oluwatoiloba, 2017). There are other versions of the creation story in Igbo cosmology that cannot be mentioned here. Among the Nri of Awka, the first human that Chukwu created was a super human and his name was Eri or Nri who was sent down to Aguleri or Enugwu$U k w u$ and later married and had children (Awolalu \& Dopamu, 1979).

Second, among the Akan, though there are many myths regarding how the earth and humankind were created, the whole explanations show that "In the beginning, [G]od made the sky. Then he made the earth, rivers, waters, plants, and trees. This was followed by the creation of the first man and woman called Okane and Kyeiwaa 
respectively". This first parent lived in a cave and was told to eat the animals and plants created by God (Awolalu \& Dopamu, 1979).

Finally, among the Urhobo people of the Niger Delta, Nigeria, Ubrurhe (2003) notes, "It is said that man was molded a lifeless being to which man could (sic) not give breath of life. All man's attempt was to no avail. In man's perplexity, Oghene came, told man to back him after which Oghene breathed on it and the molded man became a living being. Thus, the uniqueness of God's creative capability emphasized (p. 24-5). All the above myths are similar to the Hebrew account of creation in Genesis. The point here is that even though African worldview and concept of the earth/land may have/include animistic, polytheistic and pantheistic elements; that does not mean Africans did not have the idea of a supreme/creator [G]od. Ikeke (2017) thus opines, "....it will be wrong to subscribe to the theory of an "absentee-God" who is not present in creation (p. 311).

\section{Man's Relationship with the Earth/Land}

Africans believe that human beings are to a great extent, related or connected to nature. According to Turaki (2008), in many African cultures, human is believed to have:

A sense of kinship with nature, in which animals and plants, no less than human beings, had their own spiritual existence and place in the universe, as interdependent parts of a whole. [And] any object of the natural environment may enter into a totemic spiritual relationship with human beings or become tutelary and guardian spirits whilst the environment itself is used realistically and unsentimentally but with profound respect and reverence and without exploitation... This aspect [thus] reflects man's affinity with nature" (p. 162).

Africans have the understanding that there exists a relationship/affinity between man and his environment (the earth) and because of this, they worshipped and revered most natural 
elements/objects including rivers, trees, mountains and animals etcetera. Also, because of the fact that in many African societies/cultures, people often eke out their subsistence from the land; hence, for them, the land is sacred and something to revere. "It is filled with ancestral dreaming that determines kinship, sacred sites and ceremony." Africans, as well as the Aboriginals of Australia believe that the land/earth does not belong to people; people belong to land (Habel, 2008, p. 2).

Africans generally do not see any difference between the physical and the spiritual worlds. For them, they are not separate "but one and interdependent and provide a holistic view of life" (Turaki, 2008, p. 163). Corroborating the above facts, Steyne (1989) states the matter clearer: "The world interacts with itself. The sky, the spirit, the earth, the physical world, the living, and the deceased all act, interact, and react in consort. One works on the other and one part can't exist nor be explained without the other. The universe, the spirit world and man are all part of the same fabric. Each needs the other to activate it" (p. 58).

From the above observations, it is evident that for Africans, there exist no boundaries between the physical and the spiritual. They believe that both the physical and spiritual worlds are all the same and tacitly understood as inclusive in nature. Hence, 'dualism' is foreign to the people. Kwame Bediako and many other notable Afro-centric scholars have expressed these same ideas. According to Bediako, quoted in Turaki (2008), "Man lives in a sacramental universe where there is no sharp dichotomy between the physical and the spiritual. The physical acts as a vehicle for spiritual power whilst the physical realm is held to be patterned on the model of the spiritual world beyond" (p. 164). Even though this worldview/cosmology led many Africans into pantheism; however, the point is that for African people, life is governed by the law of harmony, "the goal of which is to maintain a state of agreement or peacefulness." 
Lumanze: The Concept of Land/Earth in the Old Testament and in Africa: Implications to the Contemporary Nigerian Christian

The idea of environment care is not just a Hebrew, western or Christian idea. Africans also have been practicing it before coming in contact with these foreign religions. Daneel (2001) affirms, "to the Traditional Africans, like the Israelites, ecology is inseparably linked with religion, which has further strengthened their belief that Environmental protection is sanctioned by the creator God" (p. 90). One of the most important things that this paper emphasizes or stresses on is the point that in traditional African culture, people live their lives with the consciousness that there should be harmonious and peaceful co-existence between man and nature (non-human creaturesthe earth, animals, plants). This "animistic" worldviews of Africans have implication for creation care and curbing of environmental degradation. According to Ikeke (2017), "Because of the belief of a sacred presence to a certain degree even in non-human lives (sic), they were accorded respect, reverence and preserved" (p. 79). Olusegun (2006) corroborates the above claims:

To the Africans, environmental care is not a strange concept; it was rather a way of life...some forests, rivers and streams, although dedicated to deities, were preserved, and humans prohibited from hunting or fishing in them. These habitats later became a harbor for animals presently suffering extinction resulting from the Eurocentric propaganda motivated by anthropocentric tendencies. Such tendencies led to the felling of all the trees, killing of conserved animals and fish, and then the pollution of the African source of drinking water (p. 184).

Though the researcher would not like to subscribe to animism; however, the point remains that if these beliefs and principles are put into practice today, much of the degradation of the earth will be minimized.

It is disheartening to see how westernization, modernization, urbanization and industrial/technological advancements have negatively shaped or influenced people's mindset about land/earth. 
Many people today value land only "as a place to build rather than for its productive qualities." In the contemporary society, it is evident that people's perception of land is often been coloured by their scientific and technological approach to life and nobody seems to care about "the mystery of how things grow." Many do not think of themselves as stewards of the earth, but as owners (of the resources and properties deposited/built on it) (McKeown, 2006, p. 260).

\section{Hermeneutic Re-Creation}

The significance of every of the creation myth/narrative mentioned above, lies in its symbolism; and symbols, as noted by Ogbuja (2014), are a creation of socio-cultural ordering. Cohen (1974) notes that symbols are things recognized as normally typifying other things. They are forms of communication that include items like objects, events, actions, gestures and such like. They may stand for a multiplicity of meanings, may evoke emotions and also, may push men to action. It is in the light of these that this paper picks up or gleans some of the symbolisms of Old Testament creation account and the African creation myths. First, is the matter of corporeal universalism. Based on the evidences so far, it is evident that both the Old Testament creation narrative and traditional Africans' myths of creation demonstrate or exhibit some sort of the universality of human conditions. Both narratives use "a synecdoche of generative genders to imply the generality of humanity" (Ogbuja, 2014, p. 8). Hence, like the Hebraic Yahweh Elohim, Igweand Alain Igbo cosmology, created males and females (opposite sex). In many other African cultures, the Creator-God(s) created only one species of human being; while in many others, he created different kinds of species/people. For example, among the Akan, Nyame, created a male and a female just like Ngewo of Mende and Yataa of Kono also did. They all originally created a male and female (Awolalu \& Dopamu, 1979). But from the Hebrew account, only a male and a female (Adam and Eve), were 
created by Yahweh. However, for the Igbo, as earlier noted, four males and four females were created; though this myth differs from other Igbo and African cosmologies. The point is that just like the Old Testament admits in its proto-historic narrative that Yahweh created the earth/land and humankind by Himself, many Africans have similar view of the God(s) creating the first humans who served as the source of humanity. Thus, the central motif is much greater on human origin from a Creator and his dependence on this Creator who is transcendent and above human/physical limitations.

Second, is the issue of primeval/elemental harmony. A careful observation of the creation accounts/mythical narratives of the Old Testament and traditional Africa show that there exist a harmony, unity and synergy between the Creator(s) and the creatures. Human beings, the Gods, nature, and the land all have their specifically assigned roles to play. Hence, there seems to be an accord between Yahweh/Chukwu, humanity and the land (ani); however, according to the Hebrew worldview, the first man and his wife disobeyed Yahweh Elohim and conflict/discord set in. The earth/land refused to respond to the man again in yielding abundant fruit for him; animals became hostile to him and everything turned upside down. Later on, Yahweh warns His people to be careful of what they do in the land that He was taking them to, else, the land will spur them out as it did to the Amorites and the Canaanites. Yahweh told them to give rest to their animals/land via observing the Sabbath. All these later decrees are significant in understanding the synergic relationship between human and non-human organisms and the earth/nature in general.

\section{The Implication of the Study to the Contemporary Christian}

There are many implications that are apparent, which cannot be fully outlined here; however, some of them will be examined:

First, God Owns the Earth/Land.From all indications and based on the facts provided by Old Testament texts (Gen. 1-2), the 
land/earth and everything including human and non-human organisms was designed by/for the Creator. This, according to Murekezi (2004), "is a reminder that we do not own this earth or anything in it; we are just caretakers. Therefore, we are required to guard God's properties with respect and faithfulness." Hence, even when people claim the legal right of any property, they should understand that " ... any right to private property must be circumscribed by this recognition of God's fundamental ownership of all things" (p. 60). This theological understanding/awareness of God as the Creator and Owner of the earth is not only limited to the Old Testament, it is also spelt out in the New Testament as well (cf. John 1:1-5; Acts 17: 24-31; Heb. 11:2). What is interesting and/or striking about the Hebrew (Old Testament) creation narrative is the beautiful taste and elegant/stylish industry of God. He alone took the initiative of drawing the plan of the earth and giving it fine/wonderful order, disposition and arrangement. This shows that man's earthy home is God's sacred design that "...should be protected, cared for and managed in an orderly and most circumspect manner that depicts the fear of God" (Ituma, 2013, p. 129). Original Sin does not in any way, diminish or cheapen the value that God places on His design or material Creation, namely the earth/land. God does not intend that man should deviate in protecting His design even after the Fall. All Creation belongs to God and all were made for His own pleasure and glory.

Second, there exist a relationship between man and the earth/land. According to the Old Testament and many African traditions/myths, man was created from the earth/land/ground. This is really significant. Looking at the creation account as recorded in Genesis 2, one discovers that it focuses on man and his environment (the material world). Obiora (2010) notes:

This idea is clearly accentuated in the narrative by a paronomasia between the collective name for man, adam and the name for his world adamah (ground, land). Both words sound alike and the 
narrator must have chosen them in order to underscore man's relationship to the land. In the first place, man is created from the land, from the dust of the ground (adamah) as stated in verse 7. Man's work is to cultivate the land... (p. 54).

The above observations corroborate the earlier assertion that there exists a relationship between man and the earth/ground. Many have opined that there is a wordplay here. The man was molded and/or formed from the same ground of which he was later asked to cultivate and take care of. However, there is something in him that is superior to the ground/land, namely, the breathe (spirit) of God.

Third, human beings are to be stewards of the earth/land. The two Hebrew verbs, uleshamrah and le "avedah translated "dressing" and "keeping" used in the Old Testament account of Creation (cf. Genesis 2: 15) are important in relation to earth care and stewardship. The same verb, shamar is used in Deuteronomy 5:12 concerning "keeping" the Sabbath. The Israelites are to "observe, guard and keep" the Sabbath by preserving its sanctity. The noun of this verb is "steward" or "trustee". And many scholars believe it goes deeper to refer to caring for or preservation of the earth/land." Weaver, quoted in Murekezi (2004) notes, "Stewardship implies caring management, not self-exploitation; and it involves a concern for present and future as well as self; and recognition that the world in which we live has an interest in its own survival and well being independent of its value to human beings"(p. 65). There is a difference between stewardship and ownership. And as earlier emphasized, man is not the owner of the earth/land and the rest of creation. God as the creator is still the landlord and controller of the earth and all that is in it (Psalms 24:1). He never has left this world totally for man to control; He is the controller of all things (Psalms 135:5, 6). With this understanding in mind, every living person has to see him/herself as stewards and/or caretakers who would later give account to the Creator and Owner of the earth. The same way one will give account of what s/he did with 
the body is the same way everyone will give account of what they did with the earth/land. People are to have this biblical stewardship attitude and live by it. Johnson (2000) has given this advice:

The biblical understanding of stewardship implies accountability and participation. To move beyond guilt and powerlessness, we need to move from mastery, control and ownership attitudes to an attitude of stewardship toward all of life. This means becoming caretakers of creation with a sense of identification and partnership, rather than dominion and exploitation. To be a steward of creation is to embrace the world, to love the world as Christ did, and to be willing to sacrifice for the world rather than escape from the world (p. 118).

The world will become a better place if people, starting with Christians, begin to see themselves as stewards and as partners with God in creation-care. The way God loves humankind is the way He loves His other creation. He made all things beautiful and expects people to keep them so. In fact, the Greek word, kosmos used in John 3:16 is significant. The author could have better used anthropos (humankind) to indicate that Jesus died for human beings alone; but he uses kosmos, meaning the "world" and all its inhabitants/elements. The implication is that Jesus died for the redemption of all creation including the earth/land.

Assohoto and Ngewa (2006) have underscored the significance of environment care and stewardship in a clearer term. According to them:

God provides, but he holds us responsible for maintaining what he has provided. This principle applies to us today as it applied to Adam. It is not enough to have been blessed with land; we must maintain that land and control all that could destroy it. Thus, we need to stop destructive processes like soil erosion and deforestation and must not use chemicals that are harmful to the soil (p. 14). 
Based on the above opinions stated, this study aligns with the view that the image of God in man also implies proper management and protection of the earth/ecosystems. Humankind was placed here on earth to represent God who is portrayed within the context of Genesis 1:1-2:1-15 as the Owner, Designer and Creator of the earth. God is no where presented in the pericope as one who aims to exploit what He has created. Rather, He is being presented as a Designer and Sustainer of all His creation and this should inform people on how they should interact with nature. Beer, quoted in Ituma (2013) remarks that "A good steward does not coddle the resources entrusted to him and let them lie fallow and undeveloped. Rather, he uses them, develops them and, most appropriately attempts to the best of his ability to realize their increase so that he may enjoy his livelihood and provide stewardship for the good of his family and other dependents" (p. 130).

\section{Creation Care and Holiness}

The fourth point to note is the issue of holiness in relation to creationcare. As earlier stated, the theme: "Holiness" (Heb. kedosh) or "purity" in the Old Testament is not limited spirituality or piety/piousness. It also entails cleanness, morality, and justice (sadiq) as well. Holiness and morality are translated from the same root word qadoshwhich entails moral and ethical wholeness and perfection. For this reason, God gave many laws that necessitate cleanness and neatness. Accordingly, for the Old Testament people, "impurity" was not just a spiritual matter. As earlier stated, all the laws (of washing of clothes before appearing before Yahweh, bathing, not touching dead animals/humans and excrement, not eating dead animals, not going closer to a leper et cetera) were holy laws from the holy GOD. A good example is seen in Deuteronomy 23: 12-14:

Designate a place outside the camp where you can go to relieve yourself. As part of your equipment have something to dig with, and when you relieve yourself, dig a hole and cover up your 
excrement. For the LORD your God moves about in your camp to protect you and to deliver your enemies to you. Your camp must be holy, so that he will not see among you anything indecent (unclean, impure) and turn away from you (NIV).

From the above command of Yahweh, it is His concern that His people keep and maintain a clean and pure environment. The Hebrew word used here for "holy" (kaw-doshe or kadosh) meaning "sacred" is the same word used in attributing or relating to God's holiness. Here, the word, "holy" is used in a physical sense, not spiritual. Hence, it seems to suggest that God sees land degradation/environmental pollution as unclean, indecent, and sinful. Onyezonwu (2013) has rightly observed that there are eco-theological themes embedded in the above command to the Israelites. He summarizes the passage this way:

Deuteronomy 23:12-14 presents one of the most practical and powerful biblical admonitions that states that human wastes are to be deposited outside the living area and buried...Principally, by these injunctions, the Israelites were to develop a greater reverence of God, and a greater caution to avoid all real and moral uncleanness... They must take care to keep their camp pure from moral, ceremonial and natural pollution... This charge was to teach them modesty and decorum...To properly dispose of waste is a show of reverence for divine majesty. God is not pleased when he sees filth or improperly disposed waste. These injunctions were in line with God's original purpose for man to dress, guard and keep the land, so as to remain unpolluted and clean (p. 84-5).

From the above observations, it is obvious that God hates pollution of any kind. Many have averred that pollution and rebellion has a correlation. Natural pollution breeds rebellious and harmful environment. Pollution destroys all that God originally certified 
Lumanze: The Concept of Land/Earth in the Old Testament and in Africa: Implications to the Contemporary Nigerian Christian

"good" including animals, crops, green leaves, water and land (Ucheawaji, 2013).

Furthermore, this paper has earlier noted that in the Old Testament/Israelite culture just like in many African cultures, the earth/land is not depicted as inanimate that is fit only for human use. Both cultures rather depict the earth as something that is "alive" and responsive to both God and humankind, and possessed of a dignity of its own. This dignity is reflected in various Mosaic laws given by Yahweh (Wybrow, 1990, p. 77). Even though humankind was to have dominion over the earth and over nature, however, the story of the Tower of Babel seems to suggest that this freedom and dominion is not total and should not be anthropocentric. God's role as the Creator and Guardian of the earth is apparent again in this narrative (Gen. 11:1-9). McKeown (2008) remarks that this episode shows the importance of the theme of 'eres by the six-fold repetition of the word in Genesis 11:1, 2,4,8,9 (twice). He points out:

This repetition suggests that the attitude of human beings to the earth that God has given them is one of the main issues in the Babel story. The crime of the builders is to seek selfdetermination and to find security through land without acknowledging the Creator or his rights over the land. They seek the advantages of Eden (security) without having the prerequisite harmonious relationship with the Creator. Consequently, they are scattered over all the earth, a sharp contrast to all that Eden symbolized (11:8) (p. 247).

For Wybrow (1990), “...the story of the Tower of Babel seems to say that total mastery of nature, total freedom for all human technical possibilities, is not good in God's eyes"(p. 77). All the above comments prove that the earth belongs to God and it should not be manipulated at will by humankind. For this reason, in ancient Israelite's society, their whole economic and agriculture systems were to be subjected to Yahweh's moral critique. Ucheawaji (2013) 
elaborates, "The gift of the land to live in, and the law to live by, were intrinsic to the way God shaped Israel to be a 'model' people" (p. 28). They were not to abuse the land, trees or animals. Trees were also protected under the Mosaic Law. The Israelites were not to cut down trees unnecessarily (Deut. 20: 19). The same applies in many African societies.

Once more, among the Igbo Alaor Ani (the land/earth goddess) is an active and responsive deity. Thus, often, in Igbo land and also in many traditional African societies/cultures, the Ani is to be consulted before anything is done on it. She is highly revered. She can be abused and pacified and/or appeased. Also, many trees were preserved in many African cultures. The idea of dualism (distinction between secular and divine activities) is not an African idea. Before the colonial/slave masters came to Africa, Africans saw the physical and spiritual worlds as one and the same. There was no dichotomy between the physical and the spiritual. However, when the western missionaries and anthropologists came and succeeded in tagging our worldviews "fetish", "archaic" and "uncivilized", they did everything possible to stifle them and replaced them with theirs. Thus, Africans were made to drop their own worldviews which were nature friendly and nature-centered and take up western worldviews. Turaki (2008) has observed that Western dualism has done more harm than good to the African. According to him, it has created more problems for traditional Africans who have a holistic view about nature and life in general.

Finally, is the issue of exploration and exploitation in relation to creation-care. The point is that God gave humans the earth to explore and not to exploit. Humans are thus to maintain peace/harmony in the ecosystem and sustainability of natural resources. Commenting on the two verbs used in Genesis 2: 15, Westermann (1986) asserts that the word pair, "till and watch over" makes it clear that "tilling" (Lat. Colere) without watching (caring, guarding) does not fulfill the 
commission humanity received from God the Creator. Exploiting, fouling and polluting the earth is wickedness and sin. The first assignment God gave the man He created was to protect and watch over the earth. Personally, the researcher believes that whatever humanity does with the earth should be directed at giving God the glory. Human beings have the responsibility of managing the earth for the Creator, and this responsibility is for their benefit. They are not to be exploiters of the earth resources, but are to be stewards and caretakers. This is part of and the essence of the dominion God has given humankind over creation. The exploitation of the earth and its productivity show disrespect for the Creator's intelligence.

\section{Conclusion}

The theme of "earth/land" is an important theme in both the Old Testament and the Africa. Both cultures place value on creation. However, due to industrial revolution and development, many people have abused the land/earth that God gave/commanded us to take care of. The Old Testament texts (Genesis 2, especially verse 15) among other others, reveals that man's responsibility to earth/land is encapsulated in the two Hebrew verbs: 'avad (to serve, work, care for) and shamar (to keep, observe, maintain or guard). In God's original plan and economy, all creation has important or key roles to play. The land for example, was commissioned to "bring forth living creatures (1: $24 \mathrm{NRSV}$ ). Thus, the land is addressed directly by the Creator and given a creative role to play in the ecosystem. It is of course evident that it is from the same land that the man was created from- hence, it provided the raw material for the Maker.

From the study so far, it has been observed that the Old Testament contains ecological narratives that could be ecologically relevant to the contemporary Christian. The text of the Old Testament shows that the earth (including the non-human organisms) and human beings are placed in a "symbiotic" relationship by the Creator. It 
offers principles/theoretical framework for creation care. It is unfortunate that instead of maintaining this type of (symbiotic) relationship, humankind have rather chosen to establish a "parasitic" relationship with the earth.

\section{References}

Assohoto, B. \& Ngewa, S. (2006). Africa Bible Commentary. Tokunboh Adeyemoh (ed.) Nairobi: WordAlive Publications.

Awolalu, J.O. \& Dopamu, P.A. (1979). West African Traditional

Religion. Ibadan: Onibonoje Press \& Book Industries (Nig.) Ltd.

Brueggemann, W. (2002). The Land: Place as a Gift, Promise and

Challengein Biblical Faith.

Minneapolis, MI: Fortress Press.

Cameron, W. (1990). The OT and the Conquest of Nature: A Fresh Examination." In Epworth Review 17 N0. 1. pp 77-89. Print.

Cohen, A. (1974). Two-Dimensional Man: An Essay on the Anthropology of Power and Symbolism in Complex Society. London: Routlegde and Kegan Paul.

Daneel, M. L. (2001). African Earthkeepers: Wholistic Interfaith Mission. New York: Orbis Books.

Daneel, M. L. (2001). African Earthkeepers: Wholistic Interfaith Mission. NY: Orbis Books.

Dewitt, C. B. (1991). The Religious Foundations of Ecology. The Mother Earth Handbook, Scherff, Judith S., Ed. NY: Continuum. Ezichi, I., (2013). Christocentric Ecotheology and Climate Change." In Open Journal of Philosophy 2013, Vol. 3, No. 1A. pp. 126-130 URL (last checked 23 September 2017). http://www.scirp.org/journal/ujpp.

Gehman, R.J. (2001). African Traditional Religion in the Light of the Bible. Bukuru: ACTS.

Gotlieb, R.S. (2003). Saving the World: Religion and Politics in the Environmental Movement. In Roger Gotlieb (Ed.). liberating 
Lumanze: The Concept of Land/Earth in the Old Testament and in Africa: Implications to the Contemporary Nigerian Christian

Faith: Religious Voices for Justice, Peace and Ecological Wisdom. Lanham, M.D: Roman and Littlefield.

Habel, N. \& Peter, T. (Eds.). (2008). Exploring Ecological Hermeneutics. Atlanta: Society of Biblical Literature, xiv-183. Retrieved 23 $3^{\text {rd }} \quad$ August, 2019, from http://www.brill.com/exploring-ecological-hermeneutics

Idowu, E.B. (1973). African Traditional Religion: A Definition. London: SCM Press Ltd.

Ikeke, M.O. (2017). Environmental Degradation and the Urhobo Concept of Creation: Ecophilosophical Perspectives. In the International Journal of Research in Arts and Social Sciences. Vol. 9, No.2 pp. 307-317.

KeteAsante, M. (2009). Earth. In Molefi KeteAsante and Ama Mazama (Eds.), Encyclopedia of African Religion. Los Angeles, London, New Delhi, Singapore, Washington D.C: Sage Pub. Pp. 229-230

Mbiti, J. (1991). Introduction to African Religion. Nairobi: East African Educational Publishers.

Mckeown, J. (2008). Genesis: The Two Horizons Old Testament Commentary. Grand Rapids, MI: Eerdmans Press.

Moltman, J. (1985). God in Creation. London: SCM Press.

Murekezi, F.F. (2004). Poverty, Environment and Church. A Masters thesis submitted in the School of Theology and Religion, University of Kwazulu-Natal, Pietermaritzburg, Unpublished.

Obiora, M. J. (2010). The Old Testament Narrative as a Matrix for the Concept of Human Dignity. In Nsukka Journal of Religion \& Cultural Studies. Vol. 3, N0. 1. pp 43-65.

Ogbujah, C. (2014). Exploring Myths: A Key to Understanding Igbo

Cultural

Values.http://www.researchgate.net/publication/275222640.

Olusegun, O. (2006). Africanism. Nigeria: Kofo-David Graphics. 
Oluwatobi, L. (2017). Is the Igbo Story of Creation the Real Story of Creation? - African Myth.

http:/steemit.com/culture/@ oluwatobiloba/igbostoryofcreation

Onyezonwu, L. C. (2013). Biblical Praxis for Substainable Waste

Generation and Disposal in Nigeria. In African Journal of Biblical Studies (AJBS), vol. xxxi, 1\&2, April \& Oct edition. Pp. 81-95.

Turaki, Y. (2008). Christian and Biblical Analysis of African Traditional Religion. Bukuru, Jos: ACTS.

Ubrurhe, J.O. (2003). Urobo Traditional Medicine. Ibadan: Spectrum Books.

Ucheawaji, J. (2013). Viewing Biblical Hermenutics from an African Ecological Lens. In African Journal of Biblical Studies (AJBS) 31 (1\&2), pp. 21-34.

Westermann, C. (1986). Genesis 1-11. John J.S. (Trans1.). Minneapolis: Augsburg.

Obedben Mmesomachukwu Lumanze is a lecturer in Life College of Theology, Aba, Nigeria. 